\title{
The Effect of Mission and Vision on Organizational Performance within Private Universities in Kenya
}

\author{
Bonn O. Jonyo DBA \\ USIU, Africa \\ Caren Ouma Ph.D. Associate Professor \\ Zachary Mosoti Ph.D. Assistant Professor \\ United States International University, Africa
}

URL:http://dx.doi.org/10.19044/ejes.v5no2a2

\begin{abstract}
The origins of innovation is the ability to identify global trends and to assess their relevance for development. The first area of mapping could include a better understanding of these trends in higher education and innovation around the world. The purpose of the study was to examine the effect of mission and vision on organizational performance in private universities in Kenya. The specific research question is how do mission and vision affect organization performance in private universities in Kenya? This was a correlational study which adopted a positivist philosophy. The study population comprised of all the 17 private universities in Kenya accredited by Commission of University Education. The unit of analysis was the board of directors, vice chancellors, heads of departments (finance, sports, human resource, research, quality assurance) and academic deans (business school) which was 136. A census technique was used in the study with frequency distributions, percentages and means for descriptive statistical analysis while correlations and regression analyses were used for inferential statistics. The study found that, mission and vision explained a significant proportion of variance in organizational performance, $R^{2}=.633$. The significance value in testing the reliability of the model for the relationship between Mission and Vision on organizational performance was $F(1,122)=208.929, p=0.00$. Therefore, the model was found to be statistically significant in predicting the relationship between the study variables. The study found that for every unit change in mission and vision, organizational performance increases by 0.867 hence implying a positive impact of mission and vision on organizational performance. Based on the findings, the study concluded that there was a significant relationship between all the independent variables and organizational performance the dependent variable. The study also concluded
\end{abstract}


that policy and regulation positively moderated the relationship between mission and vision and organizational performance.

Keywords: Strategic leadership, mission, vision, organizational performance.

\section{Introduction}

The late 1980s period witnessed the emergence of studies of how mission statement influences the organization's corporate image. Achua and Lussier (2016) defines organization mission statement as an enduring statement of purpose that distinguishes one organization from the other similar enterprises. It describes the business the organization pursues, and it is well explained and designed to provide many benefits to an organization, including providing direction and focus, forming the basis for objectives and strategies, inspiring positive emotions about the organization, ensuring unanimity of purpose, and helping resolve divergent views among managers (Yazhou, \& Jian, 2011). There are two components in the mission statement; the core values and the core purpose. Muchiri (2010) submits that universities are therefore compelled to chart a new strategic direction guided by a shared vision, strategic thinking and agility, taking cognizance of an increasing importance of its position in a worldwide context led by strategic leaders for organizational effectiveness.

Globalization has brought changes in higher education with dimensions of diversification on services and products, provision of more heterogeneous services, new funding arrangements, increasing focus on accountability and performance, global networking, mobility, collaboration and strategic leadership issues (Lemaitre, 2009). These changes have confronted institutional management with the need to revise and specify institutional mission statements, assess impact of new sources of funding, meet requirements for accountability, consider participation and international competition and the requirements for national, regional and international integration for their success (Spendlove, 2015). There is no doubt that higher education is facing escalating expectations and demands while at the same time experiencing serious economic shortfalls.

Strategic leadership is traditionally defined as a series of decisions and activities by a top manager (CEOs, presidents, and senior executives) in which the past, the present, and the future of the organization coalesce (Boal, 2004). That strategic leadership designates the use of the strategy process as a systematic method of decision making that integrates reciprocal leadership into its concepts and practices. Morrill, (2010) investigated how strategic leadership is applied in the American universities by situating the phenomenon within the dimensions of human moral agency and identity. This marks a new epoch of contemporary study on strategic leadership in higher education. In 
most universities and colleges, emphasis is put mainly on management but not on leadership which is understood as a process that involves setting directions, motivating others and coping with change.

According to Richard et al., (2013), defines organization performance as the actual outcomes and results of an organization as measured against its intended goals and objectives constitutes. It comprises three specific areas of the firm outcomes: financial performance such as profits, return on assets, return on investment; product market performance such as sales, market share, and shareholder return such as total shareholder return, economic value added.

Fisher and Koch (2008) also concludes that, the American university presidential authority does not need remediation of the powers of the office is no longer attainable. They describe the effectiveness of presidents who have entrepreneurial characteristics and have knowledge of the power inherent in their role. They consider that when charisma, expertise, confidence and risk taking are combined with legitimate authority, then the result is transforming and entrepreneurial leadership. This study endeavors to examine how mission and vision as a construct of strategic leadership affect organization performance in private universities in Kenya.

\section{Research Problem}

Statistics show that, in the past one decade, $57 \%$ of youthful population from developing countries pursue university education outside their home countries (UNESCO, 2014). This implies that there is a high demand for quality university education among the youth in developing countries. The high demand for university education has presented private universities with high turnover of human capital, inadequate research resources, inadequate learning infrastructure and inadequate well trained human resource, inadequate resources to manage recurrent expenditure and quality control concerns. All these have a challenge to high performance of education outcomes as set by the Commission of University Education in Kenya (MoEST, 2015). Consequently, this attracted poor ranking in the world webometrics of universities (2016). Gaps have been identified in policy adherence and enforcement areas necessary to improve processes, university boards have not lived to the expectations hence management gaps on the best practices on human resource management and financial resource mobilization for a sustainable growth and survival and a dearth of research in leadership role in universities. The question is whether this failure is due to lack of strategic leadership and management? This study therefore sought to examine the effect of mission and vision on organizational performance with reference to private universities in Kenya. 


\section{LITERATURE REVIEW \\ Theoretical Framework}

This study was underpinned by the strategic leadership theory as advanced by Ireland et al., (2013) which asserts that companies are reflections of their top managers and, the chief executive officers, and that the specific knowledge, experience, values and preferences of top managers are reflected not only in their decisions, but in their assessments of decision environments. Consequently, the significant choice options available to the CEO as the firm's key strategic leader, who often work as a 'Lone Ranger' in the organization primarily using top-down directives (Cannella \& Monroe, 1997). As a principle when these choices resulted in financial success for the company, the key strategic leader was recognized widely as the "corporate Hercules" (Senge, 2014).

\section{Conceptual Framework}

The conceptual framework for this study was derived from the strategic leadership theory as developed by Ireland and Hitt (2013).

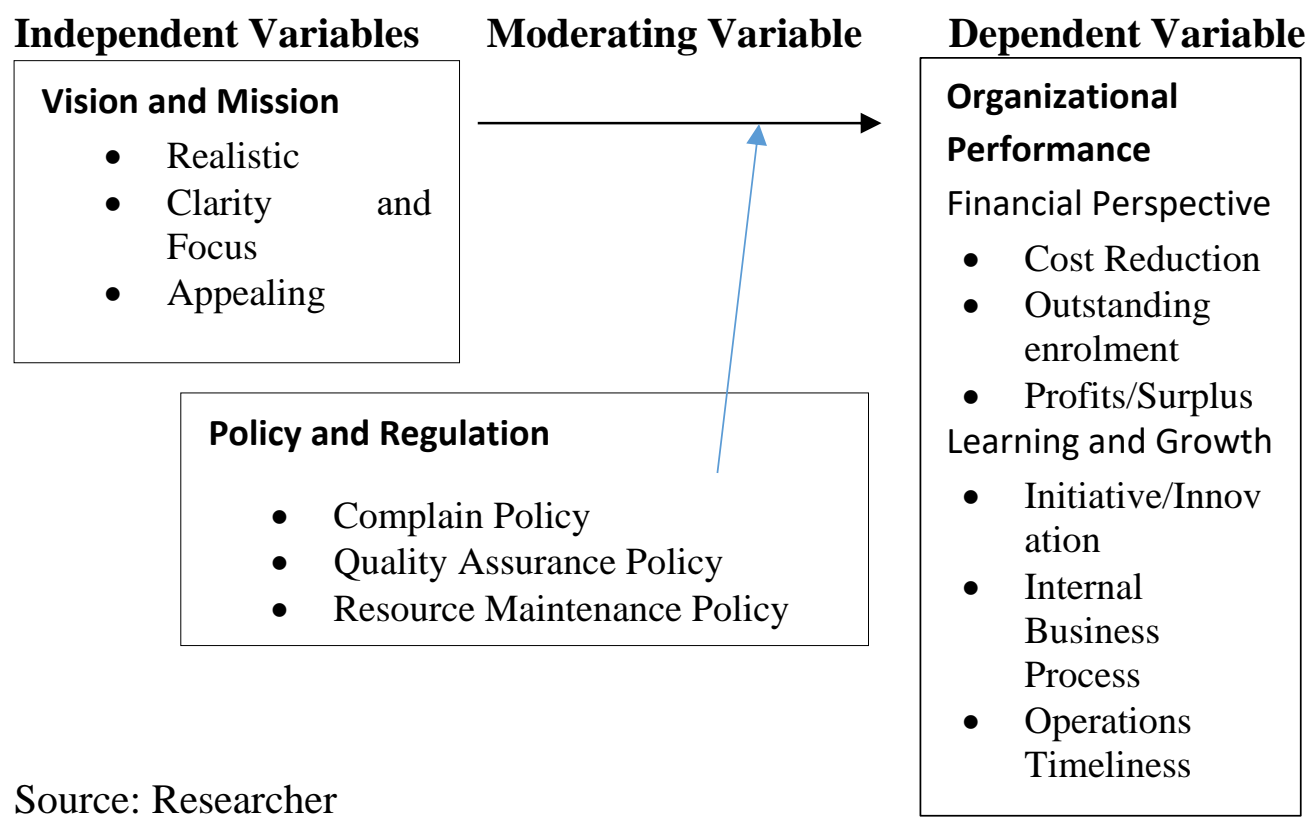

The study conceptualized a framework consisting of the dependent and independent variables to achieve the research objective (examining the effect of mission and vision on organizational performance in private universities in Kenya). The following null hypothesis derived from the research question guided the study: 
$\boldsymbol{H}_{01}$ Mission and vision do not affect the organizational performance in private universities in Kenya

The designing of the universities' strategic direction assists to direct organizational processes in terms of strategy implementation and therefore serves to communicate the mission and vision, development of the strategic objectives and the formulation of the strategic plan (Ireland, et al., 2016).

\section{Mission and vision}

Bartkus, Glassman, and McAfee (2006) concludes that, mission and vision statements have a potential for influencing the organization's performance. Ireland and Hitt, (2013) asserts that organizations do this by examining the changes that have already taken place. Subsequently, there is near certainty that a global economy is imminent and that its beginning had an impact on leadership practices today. Effective strategic leadership may prove to be one of the most critical ways for an organization to achieve superior or even satisfactory performance when confronting challenges of the global economy. Researchers agree therefore that university management need to define a strategic mission and vision statement which will have a transformative effect on the future of the institution.

Achua and Lussier (2016) defines organization mission statement as an enduring statement of purpose that distinguishes one organization from the other similar enterprises. It describes the business the organization pursues, and it is well explained and designed to provide many benefits to an organization, including providing direction and focus, forming the basis for objectives and strategies, inspiring positive emotions about the organization, ensuring unanimity of purpose, and helping resolve divergent views among managers (Yazhou, \& Jian, 2011). There are two components in the mission statement that is, the core values and the core purpose. It should be noted that mission and vision sets the stage for an organizational foundation.

Ireland et al., (2016) asserts that a good mission statement should focus on the needs that the organization's products/services are meeting. It specifies the business in which the organization intends to compete and the customers it intends to serve (customer segment). The mission statement should be broad but distinguishes the organization from the others. It should be specific but not to the extent of being rigid and difficult to operationalize. Palmer and Short (2008) noted that business schools use mission statements to present their values, motivate faculty, recruit students, and promote their accreditation aspirations. Crafting a compelling mission statement is expensive consuming relatively large quantities of institutional resources. The chances of crafting an effective mission increases when employees possess a strong focus of ethical standards that guide their behaviors as they strive to help the firm achieve its vision (Davis, Ruhe, Lee \& Rajadhyasha, 2007). Any organization without a 
proactive mission and vision is doomed in the light of competitive environment. Universities need very specific mission and vision statements which reflect the aspirations of their leaders aimed at achieving the objectives and goals as guided by the regulators.

Kantabutra and Avery (2010) argues that vision on the other hand is an ambitious view of the future that everyone within the organization can believe in and that is not readily attainable yet offers a better future than what now exists. That a good vision facilitates growth in an organization will make sense to the organization's citizens and expand their minds in terms of possibilities while at the same time remaining feasible. Stid and Bradach, (2009) concludes that a clear vision determines very critical functions such as; enhancing decision making which facilitates people to determine what is important or trivial, appealing to followers on the fundamental needs, linking and rationalizing ways of doing things, proving meaning to work and establishing a standard of excellence. As Cassar (2010) affirms that it is critical to note that a firm's vision statement reflect the values and aspirations that are intended to capture employees' heart and mind and hopefully the stakeholders' as well. This therefore denotes that the strategic leadership's job is to ensure that the vision and mission of the organization are effectively communicated and adapted by all employees. Ireland, et al., (2015) affirms that strategic leaders are people located in different areas and levels of the firm using strategic management process to select strategic actions that help the firm to achieve its vision and fulfill its mission. This kind of vision creates cohesion among members of the organization (Ireland, et.al. 2016). This makes organizations to meet their set objectives.

Once the vision has been set, the organizational members can take up the banner by designing and executing strategies to accomplish that vision. As feedback goes back to the top management, they gain the insight necessary to review the organization's vision and revise it for legitimacy and authenticity. In private universities, the top management will be focused on leveraging their human and financial capital while achieving stellar academic outcomes and excelling in co-curricular activities for the success of the institution (Kantabutra \& Avery, 2010).

Samsung incorporated has been able to use a strong vision and purpose to surprise industry analysts by creating demand where there was none. Even though the industry at the time was saturated. A bold vision was the way to leverage this strategy but of key importance is the great group taking on the challenge set by the top management and as they identify their strengths and weaknesses work together like a well-oiled machine with the focus in the penultimate objective (Ireland \& Hitt, 2015).

Thompson and Strickland, (2009) submits that an illuminating mission statement strategically, involves three critical components; customer needs or 
what is being satisfied, customer segment or who is being satisfied and lastly the firm's activities, technologies and competencies or how the firm create and deliver value to customers. Creating value to customers by defining a business by what to satisfy, whom to satisfy and how to produce the satisfaction identifies the substance of a firm. Leornard and Huang (2014) advances that mission statements have since become nearly universal paraphernalia in internal and external communications in both for and non-profit organizations, including colleges and universities. They are assumed to publicly affirm the organization's purpose and goals to its internal and external stakeholders. Therefore, a university's mission statement should communicate its own unique purpose and goals to both internal and external stakeholders.

The efficacy of a mission statement guides performance established by strategic planning and subsequent tactical initiatives purportedly designed to fulfill its goals. Leornard and Huang, (2014) asserts that a well-defined mission statement can unify and energize internal stakeholders while enhancing external stakeholders' perceptions, expectations, and possible actions. Tangible evidence of a mission statement's efficacy should be reflected in organizational performance data relevant to its stated goals. Unless a validated linkage can be demonstrated between the institution's implemented programs and activities, little is revealed of the mission statement's efficacy.

Strategic direction involves developing long-term vision of the firm's intent. A long-term vision typically looks at least five to ten years in future. Leonard and Huang, (2014) asserts that the purpose and vision of an organization aligns the actions of people across the whole organization. A genuine vision is very active and all the people in the organization understand the vision and operate with it. It is also filled with drive and energy and people are proud to talk about their organization's purpose and vision consequently positive outcomes is the result.

\section{Organizational Performance}

According to Richard et al., (2013) the actual outcomes and results of an organization as measured against its intended goals and objectives constitutes organizational performance. It comprises three specific areas of the firm outcomes: financial performance such as profits, return on assets, return on investment; product market performance such as sales, market share, and shareholder return such as total shareholder return, economic value added. Armstrong (2017) defines performance as the record of outcomes produced on a specified job function or activity during a specified period. Therefore, performance is measured in terms of output and outcome, profit, internal processes and procedures, organizational structures, employee attitudes, and 
organizational responsiveness to the environment among others (William 2002).

In recent years, many organizations have attempted to manage organizational performance using the balanced scorecard methodology (Kaplan \& Norton, 2001) where performance is tracked and measured in multiple dimensions such as: financial performance (e.g. shareholder return), customer service, social responsibility (e.g. corporate citizenship, community outreach) and employee stewardship. Balanced scorecard also identifies the measures used to monitor, review and assess performance (Armstrong, 2017). For an organization to succeed, this is contingent on the capability of its top managers, leaders and a sustainable organizational culture created by those leaders. The belief and value systems created by the leaders always influence its performance (Soebbing et al., 2015). According to Ssekakubo et al., (2015), leadership competencies have a direct positive effect and always improves employee performance. This is further affirmed by researchers who have focused on the relationship between the competencies of leaders and how their organizations perform in the world economies.

\section{Policy and Regulation}

The Ministry of Education Science and Technology (MoEST) has developed policy and legislative framework for education and training to realign the human capital development needs of the country to the Constitution and the Kenya Vision 2030. The Commission for University Education (CUE) is the main regulator of university education in Kenya. The policy on education and training therefore envisage a curriculum that successively develops the knowledge, skills, competencies, as well as lifelong learning dispositions of its citizens to meet the human capital needs of the country. Besides ensuring that learners are getting quality education and training, the Commission will consider such issues as the effectiveness of Government education policy implementation, strategic planning, resource mobilization and the management of resources by Ministries and institutions concerned with education and their management bodies. The goal is to develop a repertoire of skills and competencies necessary to achieve the objectives and goals embodied in the Constitution, 2010 and Kenya Vision 2030. The policy framework on education and training also envisages an education curriculum with parallel and complimentary tiers: academic, vocational and technical curricular. The Government will accordingly introduce a multi-track system to take care of the learning needs of all these categories of education and provide a window for the progression to higher education through any of the three tiers (MoEST, 2008). 


\section{METHODOLOGY}

The study adopted positivism research philosophy which is premised on measurable observations that lead themselves to statistical analysis. The use of appropriate research philosophy helps researchers to eliminate unrelated factors from the research (Cooper \& Schindler,2014).

The correlational design was used for this study because it has a wide range of variables and their interrelatedness (Creswell, 2014). The design was deemed suitable because this study focused on examining the effect mission and vision on organizational performance. The target population for this study included all the 17-chartered private universities with the Commission of University Education (CUE, 2016) particularly the board members, vice chancellors, academic deans (business schools) and heads of departments (finance, quality assurance, research, security, human resource and sports) as the unit of analysis with a total of 136 respondents.

The study adopted a census study in line with Israel (2009) and Rao (2015) recommendations that sample sizes of less than 200 are studied to cater for any non-response that may be encountered in the study. The estimated sample size of 136 respondents was distributed proportionate to the size of the population.

The main tool for data collection was questionnaire, preferred because it possesses a high rate of response and that the respondents can respond to the questions simultaneously hence saving time. Reliability was tested using the Cronbach's alpha. This is a measure of internal consistency that is, how closely related a set of items are as a group and it is a measure of scale reliability. A reliability coefficient of at least 0.7 Cronbach Alpha was accepted in the study. In this study, the validity of the study was ascertained by the subject experts. The analysis was done by use of; descriptive statistics to present data into charts and tables with frequency distribution and percentages as well as means and standard deviations while; inferential statistics tested the hypothesised relationships between the independent and dependent variables which included correlation and regression analyses.

\section{Diagnostic tests}

Normality test was done in the study to determine if the data set is wellmodelled by a normal distribution. In this study, normality tests were done using kurtosis and skewness. Skewness and kurtosis values that range from +/-3 (SE) are generally considered normal (Onwuegbuzie \& Daniel, 2002). Multicollinearity was done in the study using the variance inflation factors (VIF) for each variable using traditional criteria employed in the study. Linearity - The study conducted linearity test to determine whether the relationship between each of the independent variable and dependent variable was linear or not. The study findings had the homoscedasticity test evaluated 
for pairs of variables using the Levene statistic for the test of homogeneity of variances.

\section{FINDINGS AND RESULTS}

The researcher sought to examine the effect of mission and vision on organizational performance in private universities in Kenya. Data was analyzed at two levels where the first level entailed determining the organization's vision and vision. The second part involved analyzing results on the effect of mission and vision on organizational performance.

It analyzed the views of respondents on mission and vision using a table of means and standard deviations. A Likert scale data was used by rating the views in a scale. The mean results are therefore given on a scale interval where a mean value of up to 1 is strongly disagree; 1 , disagree; 2 , neutral: 3 , agree: 4 and 5 is strongly agree. Findings on mission or/and vision are shown in Table 1. From the table majority of the respondents tended to agree with the statements as indicated by the mean.

Table 1 Means and Standard Deviations for Mission and Vision

\begin{tabular}{|l|l|l|l|}
\hline & $\mathrm{N}$ & Mean (M) & $\begin{array}{l}\text { Std. } \\
\text { Deviation } \\
\text { (SD) }\end{array}$ \\
\hline $\begin{array}{l}\text { The university's vision and mission are realistic in light of its } \\
\text { resources }\end{array}$ & 124 & 4.18 & .99632 \\
\hline The university's vision and mission are clear to the employees & 124 & 4.04 & .95763 \\
\hline $\begin{array}{l}\text { The mission and vision of the university define the focus of the } \\
\text { institution }\end{array}$ & 123 & 4.27 & .82057 \\
\hline $\begin{array}{l}\text { There are clearly defined strategies that support the mission, } \\
\text { vision and ultimately the growth of the university }\end{array}$ & 120 & 4 & .87863 \\
\hline $\begin{array}{l}\text { The university's mission and vision are appealing to employees } \\
\text { in working towards realizing them }\end{array}$ & 123 & 3.81 & .96113 \\
\hline $\begin{array}{l}\text { The university's programs, services, and general activities are } \\
\text { consistent with its mission statement (growth - schools, } \\
\text { departments, research centers, labs) }\end{array}$ & 123 & 4.02 & .94941 \\
\hline $\begin{array}{l}\text { The university's planning and budgetary priorities are } \\
\text { consistent with and supportive of the mission. }\end{array}$ & 121 & 3.63 & .92577 \\
\hline $\begin{array}{l}\text { The university's actions and decisions demonstrate an } \\
\text { understanding that it serves the public and has obligations to it. }\end{array}$ & 123 & 3.98 & .89611 \\
\hline $\begin{array}{l}\text { The university's objectives/goals are consistent with its } \\
\text { mission and vision }\end{array}$ & 122 & 4.24 & .84358 \\
\hline $\begin{array}{l}\text { The implementation of the university's mission and vision is } \\
\text { based on long term objectives }\end{array}$ & 122 & 4.10 & .91281 \\
\hline $\begin{array}{l}\text { The university's strategic plan has influenced the growth and } \\
\text { expansion of its programs }\end{array}$ & 123 & 4.06 & .83274 \\
\hline
\end{tabular}




\section{Correlation between Mission and Vision, and Organizational Performance}

The findings are presented in Table 2

\begin{tabular}{|c|c|c|}
\hline & & $\begin{array}{l}\text { Organizational } \\
\text { Performance }\end{array}$ \\
\hline \multirow{3}{*}{$\begin{array}{l}\text { The university's vision and mission are realistic } \\
\text { in light of its resources }\end{array}$} & $\begin{array}{l}\text { Pearson } \\
\text { Correlation }\end{array}$ & $.570^{* *}$ \\
\hline & Sig. (2-tailed) & .000 \\
\hline & $\mathrm{N}$ & 123 \\
\hline \multirow{3}{*}{$\begin{array}{l}\text { The university's vision and mission are clear to } \\
\text { the employees }\end{array}$} & $\begin{array}{l}\text { Pearson } \\
\text { Correlation }\end{array}$ & $.559^{* * *}$ \\
\hline & Sig. (2-tailed) & .000 \\
\hline & $\mathrm{N}$ & 123 \\
\hline \multirow{3}{*}{$\begin{array}{l}\text { The mission and vision of the university define } \\
\text { the focus of the institution }\end{array}$} & \begin{tabular}{|l|l|} 
Pearson \\
Correlation
\end{tabular} & $.560^{* *}$ \\
\hline & Sig. (2-tailed) & .000 \\
\hline & $\mathrm{N}$ & 122 \\
\hline \multirow{3}{*}{$\begin{array}{l}\text { There are clearly defined strategies that support } \\
\text { the mission, vision and ultimately the growth of } \\
\text { the university }\end{array}$} & $\begin{array}{l}\text { Pearson } \\
\text { Correlation }\end{array}$ & $.547^{* *}$ \\
\hline & Sig. (2-tailed) & .000 \\
\hline & $\mathrm{N}$ & 119 \\
\hline \multirow{3}{*}{$\begin{array}{l}\text { The university's mission and vision are } \\
\text { appealing to employees in working towards } \\
\text { realizing them }\end{array}$} & \begin{tabular}{|l|} 
Pearson \\
Correlation \\
\end{tabular} & $.611^{* *}$ \\
\hline & Sig. (2-tailed) & .000 \\
\hline & $\mathrm{N}$ & 122 \\
\hline \multirow{3}{*}{$\begin{array}{l}\text { The university's programs, services, and general } \\
\text { activities are consistent with its mission } \\
\text { statement (growth - schools, departments, } \\
\text { research centers, labs) }\end{array}$} & $\begin{array}{l}\text { Pearson } \\
\text { Correlation }\end{array}$ & $.574^{* * *}$ \\
\hline & Sig. (2-tailed) & .000 \\
\hline & $\mathrm{N}$ & 122 \\
\hline \multirow{3}{*}{$\begin{array}{l}\text { The university's planning and budgetary } \\
\text { priorities are consistent with and supportive of } \\
\text { the mission. }\end{array}$} & $\begin{array}{l}\text { Pearson } \\
\text { Correlation } \\
\end{array}$ & $.637^{\text {*** }}$ \\
\hline & Sig. (2-tailed) & .000 \\
\hline & $\mathrm{N}$ & 120 \\
\hline \multirow{3}{*}{$\begin{array}{l}\text { The university's actions and decisions } \\
\text { demonstrate an understanding that it serves the } \\
\text { public and has obligations to it. }\end{array}$} & \begin{tabular}{|l|l|} 
Pearson \\
Correlation \\
\end{tabular} & $.671^{* *}$ \\
\hline & Sig. (2-tailed) & .000 \\
\hline & $\mathrm{N}$ & 122 \\
\hline \multirow{3}{*}{$\begin{array}{l}\text { The university's objectives/goals are consistent } \\
\text { with its mission and vision }\end{array}$} & \begin{tabular}{|l|l|} 
Pearson \\
Correlation
\end{tabular} & $.596^{* *}$ \\
\hline & Sig. (2-tailed) & .000 \\
\hline & $\mathrm{N}$ & 121 \\
\hline \multirow{2}{*}{$\begin{array}{l}\text { The implementation of the university's mission } \\
\text { and vision is based on long term objectives }\end{array}$} & $\begin{array}{l}\text { Pearson } \\
\text { Correlation } \\
\end{array}$ & $.515^{* * *}$ \\
\hline & Sig. (2-tailed) & .000 \\
\hline
\end{tabular}




\begin{tabular}{|l|l|l|}
\hline & $\mathrm{N}$ & 121 \\
\hline \multirow{4}{*}{$\begin{array}{l}\text { The university's strategic plan has influenced } \\
\text { the growth and expansion of its programs }\end{array}$} & $\begin{array}{l}\text { Pearson } \\
\text { Correlation }\end{array}$ & $.634^{\text {*** }}$ \\
\cline { 2 - 3 } & Sig. (2-tailed) & .000 \\
\cline { 2 - 3 } & $\mathrm{N}$ & 122 \\
\hline
\end{tabular}

Table 2 Correlation between Mission and Vision and Performance for All Items **. Correlation is significant at the 0.01 level (2-tailed).

The study sought to determine the relationship between Mission and Vision and organizational performance using correlation analysis and found that the two variables were strongly correlated $r(123)=.796, p=.000$. The results are as shown in Table 3.

Table 3 Correlation Analysis on Mission and Vision

\begin{tabular}{|l|l|l|}
\hline \multicolumn{2}{|c|}{} & $\begin{array}{l}\text { Organizational } \\
\text { Performance }\end{array}$ \\
\hline \multirow{3}{*}{ Mission and Vision } & Pearson Correlation & $.796^{* *}$ \\
\cline { 2 - 3 } & Sig. (2-tailed) & .000 \\
\cline { 2 - 3 } & $\mathrm{N}$ & 123 \\
\hline
\end{tabular}

**. Correlation is significant at the 0.01 level (2-tailed).

\section{One Way ANOVA on Mission and Vision}

A one-way ANOVA was carried out to establish if there was significant difference between the mean of Mission and Vision with number of years in leadership position at the private universities as well as the current leadership position. This was meant to determine if there was greater variability in the rating between groups and within groups. The tests established that the mean for Mission and Vision were the same for the number of years in leadership position $F(2,113)=0.308, p=0.736$. The study also found out that the mean for Mission and Vision were the same for the current leadership position, $F(3,121)=0.372, p=0.773$. Table 4 presents these results.

Table 4 One Way ANOVA for Mission and Vision

\begin{tabular}{|l|l|l|l|l|l|}
\hline \multicolumn{6}{|l|}{ Mission and Vision and Current Leadership Position } \\
\hline & $\begin{array}{l}\text { Sum of } \\
\text { Squares }\end{array}$ & df & $\begin{array}{l}\text { Mean } \\
\text { Square }\end{array}$ & F & Sig. \\
\hline Between Groups & .525 & 3 & .175 & .372 & .773 \\
\hline Within Groups & 55.433 & 118 & .470 & & \\
\hline Total & 55.958 & 121 & & & \\
\hline Mission and Vision and Years in Leadership Position \\
\hline \multicolumn{7}{|l|l|l|l|l|l|l|}{} \\
\hline Between Groups & $\begin{array}{l}\text { Sum of } \\
\text { Squares }\end{array}$ & df & $\begin{array}{l}\text { Mean } \\
\text { Square }\end{array}$ & F & Sig. \\
\hline Within Groups & 46.730 & 111 & .421 & & .736 \\
\hline Total & 46.990 & 113 & & & \\
\hline
\end{tabular}




\section{Assumptions for Regression on Mission and Vision}

The study conducted the assumptions of regression to determine whether regression analysis was suitable in the study or not. The diagnostic tests conducted in the study included normality, linearity, homoscedasticity and multicollinearity tests.

\section{Normality Test for Mission and Vision}

Prior to analyzing data using inferential statistical techniques, the study checked the normality of the data set by looking at descriptive values such as skewness and kurtosis. The skewness values obtained in the study indicated that the scores are skewed as all are negatively skewed hence no case of excessive skewness in the data. The kurtosis values also fall within the range of 0 to +5 , and therefore do not display excessive kurtosis as well. These results suggested that the normality assumption is not strictly violated in the study. Table 5 gives the results from the study.

Table 5 Normality Test for Mission and Vision

\begin{tabular}{|l|l|l|l|l|l|}
\hline & $N$ & \multicolumn{3}{l}{ Skewness } & \multicolumn{2}{l|}{ Kurtosis } \\
\cline { 4 - 7 } & Statistic & Statistic & $\begin{array}{l}\text { Std. } \\
\text { Error }\end{array}$ & Statistic & $\begin{array}{l}\text { Std. } \\
\text { Error }\end{array}$ \\
\hline $\begin{array}{l}\text { The university's vision and mission are realistic in light } \\
\text { of its resources }\end{array}$ & 124 & -1.518 & .217 & 2.364 & .431 \\
\hline $\begin{array}{l}\text { The university's vision and mission are clear to the } \\
\text { employees }\end{array}$ & 124 & -.872 & .217 & .162 & .431 \\
\hline $\begin{array}{l}\text { The mission and vision of the university define the } \\
\text { focus of the institution }\end{array}$ & 123 & -1.259 & .218 & 1.948 & .433 \\
\hline $\begin{array}{l}\text { There are clearly defined strategies that support the } \\
\text { mission, vision and ultimately the growth of the } \\
\text { university }\end{array}$ & 120 & -1.144 & .221 & 2.014 & .438 \\
\hline $\begin{array}{l}\text { The university's mission and vision are appealing to } \\
\text { employees in working towards realizing them }\end{array}$ & 123 & -.741 & .218 & .175 & .433 \\
\hline $\begin{array}{l}\text { The university's programs, services, and general } \\
\text { activities are consistent with its mission statement } \\
\text { (growth - schools, departments, research centers, labs) }\end{array}$ & 123 & -1.260 & .218 & 1.866 & .433 \\
\hline $\begin{array}{l}\text { The university's planning and budgetary priorities are } \\
\text { consistent with and supportive of the mission. }\end{array}$ & 121 & -.753 & .220 & .162 & .437 \\
\hline $\begin{array}{l}\text { The university's actions and decisions demonstrate an } \\
\text { understanding that it serves the public and has } \\
\text { obligations to it. }\end{array}$ & 123 & -.871 & .218 & .890 & .433 \\
\hline $\begin{array}{l}\text { The university's objectives/goals are consistent with its } \\
\text { mission and vision }\end{array}$ & 122 & -1.652 & .219 & 4.052 & .435 \\
\hline $\begin{array}{l}\text { The implementation of the university's mission and } \\
\text { vision is based on long term objectives }\end{array}$ & 122 & -1.457 & .219 & 2.829 & .435 \\
\hline $\begin{array}{l}\text { The university's strategic plan has influenced the } \\
\text { growth and expansion of its programs }\end{array}$ & 123 & -1.406 & .218 & 3.326 & .433 \\
\hline
\end{tabular}




\section{Linearity Test for Mission and Vision}

The study conducted linearity test to determine whether the relationship between Mission and Vision and organizational performance was linear or not. If the significant deviation from linearity is greater than 0.05 , then the relationship between the independent variable is linearly dependent. If the significant deviation from linearity is less than 0.05 , then the relationship between the independent variable and the dependent variable is not linear. According to the results shown in Table 6, the significant deviation from linearity is 0.784 which is greater than 0.05 implying than there is a linear relationship between Mission and Vision and organizational performance.

Table 6 Linearity Test for Mission and Vision and Performance

\begin{tabular}{|c|c|c|c|c|c|c|c|}
\hline & & & $\begin{array}{l}\text { Sum o } \\
\text { Squares }\end{array}$ & $\mathrm{df}$ & $\begin{array}{l}\text { Mean } \\
\text { Square }\end{array}$ & $\mathrm{F}$ & Sig. \\
\hline \multirow{5}{*}{$\begin{array}{l}\text { Organizational } \\
\text { Performance * } \\
\text { Mission or/and } \\
\text { Vision }\end{array}$} & \multirow{3}{*}{$\begin{array}{l}\text { Between } \\
\text { Groups }\end{array}$} & (Combined) & 47.225 & 32 & 1.476 & 6.909 & .000 \\
\hline & & Linearity & 42.080 & 1 & 42.080 & 196.991 & .000 \\
\hline & & \begin{tabular}{|l|} 
Deviation from \\
Linearity \\
\end{tabular} & 5.145 & 31 & .166 & .777 & .784 \\
\hline & \multicolumn{2}{|c|}{ Within Groups } & 19.225 & 90 & .214 & & \\
\hline & \multicolumn{2}{|l|}{ Total } & 66.450 & 122 & & & \\
\hline
\end{tabular}

\section{Homoscedasticity Test for Mission and Vision}

In this study, homoscedasticity refers to one of the assumptions of the study that the organizational performance gives similar amounts of variance across the range of regression values for Mission and Vision. In the study, the test for homoscedasticity requires that Mission and Vision as given in the regression equations be non-metric and the organizational performance be metric (interval or ordinal) which is the case for this study.

The study findings had the homoscedasticity test evaluated for pairs of variables using the Levene statistic for the test of homogeneity of variances. The results are then given as shown in Table 7 . From the study findings of test for homogeneity, the probability associated with the Levene Statistic $(<0.065)$ is more than the level of significance (0.05) testing at 1-tail test 5\% significance level, the researcher concludes that the variance is homogeneous.

Table 7 Homoscedasticity Test for Mission and Vision

\begin{tabular}{|l|l|l|l|}
\hline Levene Statistic & df1 & df2 & Sig. \\
\hline 1.989 & 20 & 90 & .065 \\
\hline
\end{tabular}

\section{Multicollinearity Test for Mission and Vision}

Multicollinearity is a state of very high intercorrelations or interassociations among the independent variables. Multicollinearity in the study was checked using the variance inflation factors (VIF). The VIF values of between 1 and 10 show that multicollinearity is not problematic in the study while VIF values of less than 1 and more than 10 indicate multicollinearity 
issues in the study. The findings obtained indicated that the VIF value for organization's mission or/and vision is 2.269 which is betweeen 1 and 10 and therefore multicollinearity was not problematic in the study. The findings are shown in Table 8.

Table 8 Multicollinearity Test for Mission and Vision

\begin{tabular}{|l|l|l|l|}
\hline \multirow{2}{*}{ Model } & \multicolumn{3}{|l|}{ Collinearity Statistics } \\
\cline { 3 - 4 } \multicolumn{1}{|l}{1} & Tolerance & VIF \\
\hline \multirow{3}{*}{1} & Organization's Mission and Vision & 441 & 2.269 \\
\cline { 2 - 4 } & Human Capital Development & .240 & 4.173 \\
\cline { 2 - 4 } & Organizational Culture & .321 & 3.120 \\
\cline { 2 - 4 } & Ethical Values & .248 & 4.037 \\
\cline { 2 - 4 } & Strategic and Financial Controls & .257 & 3.898 \\
\hline
\end{tabular}

a. Dependent Variable: Organizational Performance

\section{Hypothesis Testing for Mission and Vision}

Regression analysis is a statistical method that deals with the formulation of mathematical model depicting relationship amongst variables which can be used for the prediction of values of the dependent variables, given the values of the independent variables. Based on linear regression model, the study sought to establish the effect of Mission and Vision on organizational performance. The following hypothesis was therefore tested: Hol: Mission and Vision does not affect the organizational performance in private universities in Kenya.

The study found that Mission and Vision explained a significant proportion of variance in organizational performance, $\mathrm{R}^{2}=.633$. This implies that $63.3 \%$ of the proportion in organizational performance can be explained by Mission and Vision in private universities in Kenya. Other factors not covered by this study therefore contribute to $36.7 \%$. Findings are as shown in Table 9.

Table 9 Model Summary for Mission and Vision

\begin{tabular}{|l|l|l|l|l|}
\hline Model & R & R Square & Adjusted R Square & $\begin{array}{l}\text { Std. Error of the } \\
\text { Estimate }\end{array}$ \\
\hline 1 & $.796^{\mathrm{a}}$ & .633 & .630 & .44879 \\
\hline
\end{tabular}

a. Predictors: (Constant), Mission and Vision

The findings indicate that the significance value in testing the reliability of the model for the relationship between Mission and Vision on organizational performance was $F(1,122)=208.929, p=0.00$. Therefore, the model is statistically significant in predicting the relationship between the study variables. Results are as presented in Table 10. 
Table 10 ANOVA for Mission and Vision

\begin{tabular}{|l|l|l|l|l|l|l|}
\hline \multicolumn{2}{|l|}{ Model } & Sum of Squares & df & Mean Square & F & Sig. \\
\hline \multirow{3}{*}{1} & Regression & 42.080 & 1 & 42.080 & 208.929 & $.000^{\mathrm{b}}$ \\
\cline { 2 - 8 } & Residual & 24.370 & 121 & .201 & & \\
\cline { 2 - 8 } & Total & 66.450 & 122 & & & \\
\hline
\end{tabular}

a. Dependent Variable: Organizational Performance

b. Predictors: (Constant), Mission and Vision

The study found that Mission and Vision significantly predicted organizational performance, $\beta=.796, t(122)=14.454, p=.000$. This finding implied rejection of the null hypothesis since the $\mathrm{p}$ value was less than $<.05$ set by the study. The study therefore concluded that Mission and Vision significantly influences organizational performance in private universities in Kenya. The results are presented in Table 11.

Table 11 Coefficients for Mission and Vision

\begin{tabular}{|c|c|c|c|c|c|c|}
\hline \multirow{2}{*}{\multicolumn{2}{|c|}{ Model }} & \multicolumn{2}{|c|}{$\begin{array}{l}\text { Unstandardized } \\
\text { Coefficients }\end{array}$} & \multirow{2}{*}{\begin{tabular}{|l|l|}
$\begin{array}{l}\text { Standardized } \\
\text { Coefficients }\end{array}$ \\
Beta \\
\end{tabular}} & \multirow[t]{2}{*}{ t } & \multirow[t]{2}{*}{ Sig. } \\
\hline & & $\mathrm{B}$ & Std. Error & & & \\
\hline \multirow{2}{*}{1} & (Constant) & .344 & .245 & & 1.403 & .163 \\
\hline & Mission and Vision & .867 & .060 & .796 & 14.454 & .000 \\
\hline
\end{tabular}

a. Dependent Variable: Organizational Performance

The findings obtained in the study imply that for every one-unit change in Mission and Vision, organizational performance increases by 0.867 hence implying a positive impact of Mission and Vision on organizational performance.

\section{DISCUSSIONS AND CONCLUSIONS}

The study found that, organization's mission and vision explained a significant proportion of variance in organizational performance, $\mathrm{R}^{2}=.633$. This implies that $63.3 \%$ of the proportion in organizational performance can be explained by organization's mission and/or vision in private universities in Kenya. The significance value in testing the reliability of the model for the relationship between Mission and Vision on organizational performance was $F(1,122)=208.929, p=0.00$. Therefore, the model is statistically significant in predicting the relationship between the study variables. That for every oneunit change in organization's mission and vision, organizational performance increases by 0.867 hence implying a positive impact of organization's mission and vision on organizational performance.

\section{Conclusion}

Based on the findings and discussions of the study, the study concluded that organization's mission and vision explained a significant proportion of variance in organizational performance. In addition, the study concluded that 
for every one-unit change in organization's mission and vision, organizational performance increases by 0.867 hence implying a positive impact of organization's mission and vision on organizational performance.

\section{Recommendations}

The study determined that the universities' planning and budgetary priorities were not highly consistent with and supportive of their missions and that the universities' missions and vision were not highly appealing to employees in working towards realizing them. The study therefore recommends that the universities' budgetary and planning priorities need to be aligned to their missions, in order to improve performance. Additionally, employees need to be trained as far as the universities' missions and visions are concerned, in order for them to work towards their realization

\section{References:}

1. Academic Ranking of World Universities (2016), Institute of Higher Education, Shanghai Jiao Tong University.

2. Achua C.F. \& Lussier, R.N. (2016) Leadership: theory, application, \& skill development, Sixth edition. Boston, MA CENGAGE Learning, USA

3. Armstrong, M. (2017), Armstrong's Handbook of Performance Management: An Evidence-Based Guide to Delivering High Performance, 6th. Kogan PAGE: London.

4. Bartkus, B., Glassman, M., \& McAfee, B. (2006). Mission statement quality and financial performance. European Management Journal, 24, 86-94.

5. Boal, K. B. (2004). Strategic leadership. In: G. R. Goethals, G. J. Sorenson \& J. M. Burns(Eds), Encyclopedia of leadership (pp. 14971504). Thousand Oaks, CA: SAGE.

6. Cannella, A. A. Jr. \& Monroe, M. J. (1997) Contrasting Perspectives on Strategic Leaders: Toward a More Realistic View of Top Managers, Journal of Management, 23, 213-237

7. Cassar, G. (2010), Are individual entering self-employment overlay optimistic? An empirical test of plans and projections on nascent entrepreneur expectations, Strategic Management Journal, 31: 822840.

8. Cooper, D. \& Schindlers, P. (2014). Business Research Methods 12th Ed. New York MCGRAW HILL Irwin

9. Creswell, J. W. (2014). Designing and Conducting Mixed Methods Research (4ndEd) Thousand Oaks, CA: SAGE. 
10. Davis, J. H., Ruhe, J. A. Lee, M. \& Rajadhyasha (2007) Mission possible: Do school mission statements work? Journal of Business Ethics, 70, 99-110.

11. Fisher, J. L. \& Koch, J. V. (2008). Born, not made. The entrepreneurial personality. London: Praeger.

12. Ireland, R. D., Hoskisson, R.E. \& Hitt, M. A. (2013), The Management of Strategy Concepts and Cases, $10^{\text {th }}$ ed. Mason, OH: South-Western CENGAGE Learning.

13. Israel, G. D. (2009) Determining Sample Size. Program Evaluation and Organizational Development, Institute of Food and Agricultural Sciences (IFAS), University of Florida, Gainesville, USA

14. Kantabutra, S. (2010),"Vision effects: a critical gap in educational leadership research", International Journal of Educational Management, Vol. 24 Iss 5 pp. 376 - 390.

15. Kantabutra, S. \& Avery, G. (2010), The Power of Vision: Statement That Resonate, Journal of Business Strategy 31(1): 37-45

16. Kaplan R.S. \& Norton, D.P. (2001), The strategy focused organization, Strategy \& Leadership, 29(3): 41-42; R.S. Kaplan \& D.P Norton, 2000, The Strategy-Focused Organization: How Balanced Scorecard Companies Thrive in the New Business School Press.

17. Lemaitre, M. (2009). Quality Assurance in a Changing World. INQAAHE Conference. Abu Dhabi, March.

18. Leonard, W.P \& Huang, C.H. (2014), Linking Classroom Performance to the Institutional Mission Statement, SAGE Open Journal, JanuaryMarch 2014: 1-8

19. MoEST: (2015) Educational for All Review.

20. Morrill R. L. (2010) Strategic Leadership, Integrating Strategy and Leadership in Colleges and Universities, Rowman Littlefield Publishers INC, NY USA.

21. Muchiri, P., Pintelon, L, Gelders, \& Martin, H. (2010). Development of Maintenance Function Performance Measurement Framework Indicators. International Press.

22. Palmer, T. B., \& Short, J. C. (2008). Mission statements in U.S. colleges of business: An empirical examination of their content with linkages to configurations and performance. Academy of Management Learning \& Education, 7, 454-470.

23. Rao, J. N. (2015). Small-Area Estimation. John Wiley \& Sons, Ltd.

24. Richard A. (2013), Theory Building in Applied Disciplines. San Francisco, CA: Berrett-Koehler Publishers.

25. Sawyer, A. (2004), Challenges Facing African Universities: Selected Issues. African Studies Review, Vol.47, No.1, pp.1-59. 
26. Senge, P.M. (2014). The dance of change: The challenges to sustaining momentum in a learning organization. Random House LLC

27. Spendlove, M (2015) Competencies for Effective Leadership in Higher Education. International Journal of Educational Management Vol 21 No 5 pp 407-417.

28. Soebbing, B.P., Wicker, P. \& Weimar, D. (2015), "The impact of leadership changes on expectations of organizational performance", Journal of Sport Management, Vol. 29 No. 5, pp. 485-497.

29. Ssekakubo, J., Lwanga, F. \& Ndiwalana, G. (2014), "Employee motivation, job satisfaction and organizational performance in Uganda's oil sub-sector", Global Advanced Research Journal of Management and Business Studies, Vol. 3 No. 7, pp. 315-324.

30. Thompson, B. (2006), Foundations of behavioral statistics: An insight-based approach. New York: Guilford.

31. Tomal, D.R. \& Jones, K.J. (2015), "A comparison of core competencies of women and men leaders in the manufacturing industry", The Coastal Business Journal, 14 (1), 13-25.

32. Thompson, A.A. \& Strickland, A.J. (2009). Crafting and Executing Strategy, 17th edition. New York: McGraw-Hill: USA

33. UNESCO, (2014) Research and Experimental Development, Institute for Statistics

34. UNESCO, (2011), Financing Education in Sub-Saharan Africa. Meeting the Challenges of Expansion, Equity and Quality, Montreal: UNESCO Institute for Statistics.

35. Varghese, N.V. (2006), Growth and expansion of private higher education in Africa. Paris: IIEP-UNESCO.

36. Varghese, N.V (2004), UNESCO, Growth and Expansion of Higher Education, New Trends.

37. Varghese, N.V (2004), Incentives \& institutional changes in higher education management \& policy, 16 (1), 27-40 